\title{
ON PRESSING MCNOLLGAST TO THE LIMITS: THE PROBLEM OF REGULATORY COSTS
}

\author{
Michael ASIMOW*
}

\section{I \\ InTroduction: The Purposes of Rulemaking Procedure}

Recent scholarship by Mathew D. McCubbins, Roger G. Noll, and Barry R. Weingast, ${ }^{1}$ and by Arthur Lupia and McCubbins, ${ }^{2}$ sheds new light on an important administrative law subject: the rationale for and the utility of the procedures that an administrative agency must follow in order to adopt rules. According to the Administrative Procedure Act ("APA"), an agency must give public notice of a proposed rule and allow any interested person to provide written comments on that rule. ${ }^{3}$ The agency must also supply a concise statement of the basis and purpose of a rule when it is adopted. ${ }^{4}$ A final rule must be published in the Federal Register, ${ }^{5}$ and its effective date must be delayed until thirty days after publication. ${ }^{6}$

What purposes does the notice-and-comment procedure serve? While the legislative history of the APA is unilluminating, courts and commentators have identified two significant purposes. The first is utilitarian, and the second is drawn from political theory.

The utilitarian purpose is that the notice-and-comment procedure produces better rules than a regime lacking such procedure. When evaluated by the conventional utilitarian calculus, ${ }^{7}$ this congressional insight seems correct. The

Copyright $\mathbb{C} 1994$ by Law and Contemporary Problems

* Professor of Law, UCLA School of Law.

Jonathan Baker reviewed this manuscript and provided invaluable suggestions.

1. These three authors combined parts of their last names to create the author acronym "McNollgast" [hereinafter they will be cited and referred to as McNollgast]. McNollgast, Administrative Procedures as Instruments of Political Control, 3 J.L. EcON. \& ORG. 243 (1987) [hereinafter McNollgast, Administrative Procedures]; McNollgast, Structure and Process, Politics and Policy: Administrative Arrangements and the Political Control of Agencies, 75 VA. L. REV. 431 (1989) [hereinafter McNollgast, Structure and Process].

2. Arthur Lupia \& Mathew D. McCubbins, Designing Bureaucratic Accountability, 57 LAw \& CONTEMP. PROBS. 91 (Winter 1994).

3. The Administrative Procedure Act was adopted in 1946. The current version of the notice and comment provisions is 5 U.S.C. $\$ 553$ (b) and (c) (1988). The Act will be cited herein as APA without the prefatory cite to U.S.C.

4. APA \& 553(c).

5. Id. § 552(a)(1)(D).

6. Id. $\S 553(\mathrm{~d})$.

7. See, e.g., Roger C. Cramton, A Comment on Trial-Type Hearings in Nuclear Power Plant Siting, 58 VA. L. Rev. 585, 591-93 (1972); Paul Verkuil, The Emerging Concept of Administrative Procedure, 
conventional approach balances three factors: accuracy, efficiency, and acceptability. Accuracy refers to whether the procedure is likely to produce an outcome that is best aligned with available data, is most rational, and most closely approximates the result the legislature would have produced had it considered the issue. Efficiency means reaching the outcome at the lowest cost to government and to affected private interests and with the least delay. Acceptability means that the procedure seems fair to the interests affected by the outcome. Since these three factors often point in different directions, design of the most appropriate procedure to effectuate a specific function often calls for a somewhat intuitive balancing act. Several generations of commentators have agreed that the APA's notice-and-comment procedure strikes a pretty good balance.

With respect to accuracy, the APA's notice provision makes it likely that interested parties will find out about a proposed rule and will submit comments designed to influence the decisionmakers. Both outsiders and other agencies are welcome to furnish input, either on the record or ex parte, ${ }^{8}$ resulting in a large base of data and opinion. ${ }^{9}$ As a result, the rulemaking agency must focus its attention on the political implications of the proposed rule as well as on the rule's practical costs and benefits. All this seems well calculated to produce "accurate" outcomes: ones that are informed by available data but that also reflect the political preferences of commentators and the chief executive. ${ }^{10}$

Yet the APA rulemaking procedures seem relatively efficient. They forgo time-consuming steps such as cross-examination and, as originally conceived, contained no special requirements for consultation, scientific studies, submission of proposed rules to outside agencies, or findings of fact.

Finally, these procedures seem relatively acceptable to the people who must live with the resulting rules-both beneficiaries of the rules and persons to be regulated by them. Such persons have an opportunity to place their views on the record and to examine and respond to the submissions of other parties. The agency cannot make too large a change from proposed to final rule without reproposing the rule. ${ }^{11}$ As embellished by court decisions, the APA requires the agency to respond to material comments, so that commentators are assured

78 COLUM. L. REV. 258, 279-93 (1978).

8. Sierra Club v. Costle, 657 F.2d 298, 404-08 (D.C. Cir. 1981).

9. According to case law, an agency must make available critical data in its files, such as test results or other technical data, in time for commentators to evaluate and criticize it. Portland Cement Ass'n v. Ruckelshaus, 486 F.2d 375, $392-94$ (D.C. Cir. 1973), cert. denied, 417 U.S. 921 (1974). This requirement makes it more likely that the comment process will entail a genuine interchange that is likely to produce a more accurate rule.

10. This conclusion holds regardless of whether the observer adheres to the transmission belt, expertise, pluralism, or civil republication models of administrative law. See Mark Seidenfeld, $A$ Civic Republication Justification for the Bureaucratic State, 105 HARV. L. REV. 1511, 1513-16, 1559-62 (1992); see generally Richard B. Stewart, The Reformation of American Administrative Law, 88 HARV. L. REV. 1667 (1975).

11. If a final rule is not the "logical outgrowth" of the proposed rule, the agency must repropose the rule. BASF Wyandotte Corp. v. Costle, 598 F.2d 637, 642 (1st Cir. 1979). 
that their inputs are at least considered. ${ }^{12}$ Judicial review is generally available and, at the review stage, courts scrutinize both the legality and the reasonableness of a final rule. While regulatees would probably prefer trial-type protections, the APA package of administrative and judicial process provides an acceptable compromise.

In addition to this utilitarian rationale, the APA rulemaking procedure has a second important purpose: it provides an ingenious substitute for the lack of electoral accountability of agency heads. Indeed, rulemaking procedures are refreshingly democratic: people who care about legislative outcomes produced by agencies have a structured opportunity to provide input into the decisionmaking process. In this respect, the agency lawmaking process is vastly superior to the unstructured and chaotic procedures of the legislature. Congressional lawmaking is, all too often, characterized by behind the scenes dealmaking with special interests who have made large campaign contributions.

II

\section{MCNOLlgast AND REgUlatory COSTS}

Now how does all this relate to McNollgast's work? They posit an additional purpose for rulemaking procedure, one wholly distinct from those already mentioned: rulemaking procedure serves as a "fire alarm."13 The procedure energizes constituents who will alert legislators to instances in which agencies stray from the path of righteousness. In particular, the fire alarms will inform the legislators, who formed the coalition that originally delegated rulemaking authority, that the agency contemplates action that departs from the legislative deal.

McNollgast's work ties in with a long tradition of political criticism of overbroad delegations as an abdication of legislative responsibility. ${ }^{14}$ Instead of criticizing such delegations, however, McNollgast accepts them as inevitable and focuses on the principal-agent problem inherent in broad delegations. ${ }^{15}$

\footnotetext{
12. Rodway v. United States Dep't of Agric., 514 F.2d 809, 817 (D.C. Cir. 1975).

13. McNollgast, Administrative Procedures, supra note 1; McNollgast, Structure and Process, supra note 1

14. See, e.g., TheOdore J. LowI, The END OF Liberalism: IDEOLOGY, POLICY, AND THE CRISIS OF PUBLIC AUTHORITY 29-33 (2d ed. 1969); Peter Aranson et al., A Theory of Legislative Delegation, 68 CORNELL L. REV. 1, 63-77 (1983). I tend to regard the congressional abdication and agency illegitimacy arguments as unpersuasive. The odds are that the problem will be solved better, with lower implementation costs, by allowing an agency broad discretion to deal with it rather than by tying its hands in advance by overly detailed and restrictive statutory delegations. See Jerry L. Mashaw, Prodelegation: Why Administrators Should Make Political Decisions, 1 J.L. ECON. \& ORG. 81 (1985); Karla W. Simon, Congress and Taxes: A Separation of Powers Analysis, 45 U. MIAMI L. REV. 1005, 1014-49 (1991).

15. I appreciate the fact that McNollgast's work is free from the assumption, prevalent in public choice literature, that agency decisionmakers are simply profit maximizers whose actions can be modeled on the assumption that they seek only to expand their empires or stuff their own wallets. Instead, McNollgast assumes that agencies pursue their own vision of the public interest, but recognizes that this
} 
Given that the legislature has failed to spell out what it wants, McNollgast seeks relatively cheap oversight devices that a legislature might adopt to keep the agency faithful to the original deal struck by the enacting coalition.

McNollgast identifies administrative procedure as the answer. They claim that the APA's rulemaking process stacks the deck in favor of the interests intended to be favored by a regulatory scheme. These interests furnish data inputs to agency decisionmakers. These inputs influence ultimate outcomes in the direction the enacting coalition would have preferred if it had resolved the issue when it passed the law. Moreover, favored constituencies can trip the legislative fire alarm and thereby alert legislators that some administrative monkey business is going on. Once the alarm sounds, congressional fire brigades will arrive to douse the fire. Knowing that this is likely to occur, agencies are constrained ex ante from attempting tricky moves away from the coalitional preference. Lupia and McCubbin's insightful article advances the ball by suggesting that these procedures remain useful even given the possibility that both agencies and constituents may send false signals to a relatively uninformed legislature. ${ }^{16}$

I do not doubt that Congress has sometimes fashioned administrative procedures that have a deck-stacking function. In particular, the legislature sometimes goes beyond the APA rudiments and crafts elaborate "hybrid" or super-APA procedural requirements that do seem to favor particular constituencies. And I agree that APA rulemaking procedure, along with hybrid procedure, sometimes proves useful in implementing statutes and facilitating legislative oversight. ${ }^{17}$

Nevertheless, I am skeptical of the claim that the McNollgast hypothesis provides a descriptive account of what Congress intended when it enacted the basic APA administrative procedure conventions or even most hybrid procedures. ${ }^{18}$ The oversight-facilitation purpose of rulemaking procedure seems much less important than the purposes already pointed out: producing accurate rules in an acceptable manner at the least cost and helping to legitimate decisionmaking by electorally unaccountable elites. Certainly, if any members of Congress had oversight facilitation in mind when they adopted the rulemaking procedures in the APA, they kept that purpose wholly to themselves. To my

vision might be at variance with that embodied in the original legislative bargain.

16. Lupia \& McCubbins, supra note 2.

17. See Daniel A. Farber, Politics and Procedure in Environmental Law, 8 J.L. ECON. \& ORG. 59, $72-73$ (1992) (environmental groups play crucial rule in implementing environmental statutes).

18. Congress generally states that the extra steps it sometimes prescribes will produce better, more carefully considered rules. It says nothing about protecting favored interests or facilitating oversight. See Craig N. Oren, Clearing the Air: The McCubbins-Noll-Weingast Hypothesis and the Clean Air Act, 9 VA. ENVTL. L.J. 45, 80-97 (1989) (refuting McNollgast account of purpose of hybrid procedures in Clean Air Act). In other situations, hybrid procedures seem intended largely as bones thrown to losers in the legislative process; the losers hope that the hybrid procedures will be so onerous that they will prevent the agency attorney from doing very much. 
knowledge, no trace of that purpose emerges in the legislative history of the Act or of the reports that led up to it. ${ }^{19}$

If one abandons the notion that the purposes of the APA (or of most superAPA hybrid procedures) were facilitation of oversight and protection of the original legislative deal, can one at least assert that the procedures have this fortuitous good effect? Perhaps, but the APA procedures are designed in a pretty clumsy manner to achieve that result.

It is difficult to understand how the standard notice-and-comment rulemaking procedure of the APA does much to preserve the original balance struck by the legislative coalition that enacted the bill-assuming the coalition even reached agreement on the issue as opposed to papering it over through a vague delegation to an agency to solve the problem. ${ }^{20}$ Rulemaking procedure gives exactly the same participation opportunity to groups that opposed the original legislation as to those that supported it. ${ }^{21}$ To the extent the standard APA procedure influences outcomes, it tends to help the interest groups who are best organized at the time the rule is proposed-who may well have been the losers in the original legislative combat. And when groups that oppose agency action trip legislative fire alarms, the fire will be doused (or fed or ignored) by the existing power balance in the legislature rather than by the coalition that existed at the time the legislation was enacted. ${ }^{22}$

Still, the McNollgast hypothesis does seem to explain at least some superAPA hybrid procedures that serve a deck-stacking function. Thus it is helpful in understanding and critiquing rulemaking procedures. But is their hypothesis totally benign? My problem is this: if one takes McNollgast's insights seriously and presses them to their logical limits, one might be troubled by the relatively poor fit between the oversight-facilitation purpose and the design of the existing procedures. A response to this concern might be to pile some new and better designed procedures atop the existing ones. At that point, the McNollgast theory would slip from description to normative prescription. And, inevitably, such new procedures would be costly. I want to urge that this temptation be resisted.

What sorts of costly new procedures might a McNollgast disciple be in favor of? Lupia and McCubbins, concerned that an agency might lie to the legislature,

19. See AtT'y Gen. Comm., Administrative Procedure in Government Agencies; S. Doc. No. 8, 77th Cong., 1st Sess. 102-15 (1941). The Attorney General's Committee did not recommend that Congress enact mandatory rulemaking procedures, but it praised the procedures already used by agencies. These procedures give opportunity to all persons affected to present their views and elicit systematically the information necessary to fair and intelligent action.

20. More often than not, even super-APA hybrid procedures are poorly designed for protecting coalitional deals or facilitating oversight. See Glen O. Robinson, Commentary on "Administrative Arrangements and the Political Control of Agencies": Political Uses of Structure and Process, 75 VA. L. REV. 483, 489-95 (1989).

21. See Jeffrey S. Hill \& James E. Brazier, Constraining Administrative Decisions: $A$ Critical Examination of the Structure and Process Hypothesis, 7 J.L. ECON. \& ORG. 373, 393-94 (1991). Hill and Brazier observe that judicial doctrines liberally permitting standing to seek judicial review, or allowing hard look judicial review, are as likely to benefit interests opposed to the regulatory scheme as those that were part of the enacting coalition.

22. Id. at 384; Robinson, supra note 20, at 495; Seidenfeld, supra note 10, at 1526-27. 
appear to favor a system of penalties to make lies more costly to the agency. ${ }^{23}$ They would probably also support installation of a verifier function whenever possible. Indeed, Lupia and McCubbins seem to favor cost-raising techniques as a positive good since the existence of high agency costs itself gives valuable information to the legislature about the agency's preferences. ${ }^{24}$

This logic might lead McNollgast devotees to favor more frequent use of deck-stacking techniques in statutes creating regulatory schemes. One common form of deck-stacking is mandatory consultation by the agency with carefully constituted advisory committees or scientific panels. ${ }^{25}$ Another promising idea is subjecting the agency to exogenous control over its agenda. ${ }^{26}$ Hardy deckstacking perennials include requirements to produce impact statements ${ }^{27}$ or elaborate cost-benefit or regulatory analyses before taking action. ${ }^{28}$ Subsidies or cost reimbursements to certain kinds of favored participants would reduce their entry costs and thus help to assure their participation. McNollgast enthusiasts might favor legislative vetoes, ${ }^{29}$ or at least mandatory submission of a proposed rule to legislative committees or to the drafters of the original bills. $^{30}$ They should be strongly in favor of Administrative Rule Review Committees, such as exist in some states ${ }^{31}$ and in the United Kingdom. ${ }^{32}$

23. Lupia and McCubbins are not very clear about the sort of penalties they have in mind. One penalty they seem to favor is judicial reversal of agency action. Undeniably a judicial order to an agency to start from scratch is costly to the agency and thus a potent deterrent. Other sanctions that Lupia and McCubbins might favor would include bad publicity in the media, a nasty oversight hearing before a legislative committee, an appropriation rider, or, at the limit, total defunding of the agency or an agency function. But, as McNollgast's earlier work indicates, such sanctions are costly to both the principal and the agent and should be avoided. McNollgast, Administrative Procedures, supra note 1, at 273 . See Jerry L. Mashaw, Improving the Environment of Agency Rulemaking: An Essay on Management, Games, and Legal and Political Accountability, 57 LAW \& CONTEMP. PROBS. 185 (Spring 1994) (oversight hearings can degenerate into circuses).

24. Lupia \& McCubbins, supra note 2, at 106-07.

25. See generally Thomas O. McGarity, Some Thoughts on "Deossifying " the Rulemaking Process, 41 DUKE L.J. 1385, 1407-10 (1992).

26. McNollgast, Administrative Procedures, supra note 1, at 267 (referring to the Consumer Product Safety Commission and the Occupational Safety and Health Administration).

27. The environmental impact statement is the most prominent of such requirements. Among numerous others that have been used or still exist are required analyses of the impact of a rule on small business, families, foreign trade, and federalism. McGarity, supra note 25, at 1400-07.

28. See Exec. Order No. 12,291, 46 Fed. Reg. 13,193 (1981), reprinted in 5 U.S.C. $\$ 601$ (1988) (requiring preparation of regulatory impact statements). Executive Order 12,291 has been superseded by Executive Order 12,866, 58 Fed. Reg. 51,735 (1993), which also requires agencies to consider costs, benefits, and alternatives of significant rules but dispenses with formal regulatory impact statements.

29. Legislative vetoes were invalidated in INS v. Chadha, 462 U.S. 919 (1983). However, they might be valid under state constitutions.

30. See CAL. Gov'T CODE $\S 11,017.5$ (b) (West 1992) (agency must file reports with author of statute and notify author of all proposed regulations implementing statute as long as the author is a member of the legislature).

31. See Model State Administrative Procedure ACT $\$ \$ 3-203,3-204,15$ U.L.A. 1 (1990);

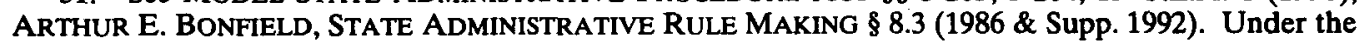
Model Act, if the A.R.R.M. objects to a rule, the burden shifts to the agency on judicial review to establish that the rule is within the procedural and substantive authority delegated to the agency. Model State Administrative Procedure ACT § 3-204(d)(5).

32. Michael Asimow, Delegated Legislation: United States and United Kingdom, 3 OXFORD J. LEGAL STUD. 253, 266 (1983). 
McNollgastians would be relatively indifferent to delays, because they might prefer a ponderous, slowed-down rulemaking calendar. A deliberate pace tends to prevent a fait accompli and provides plenty of chances for the fire alarms to study the implications of proposed agency action and to get in touch with their chosen Congressperson. ${ }^{33}$ For example, multiple rulemaking cycles would give the legislature a good opportunity to intervene in the process. To force everything into the open, accessible to members of the public and Congress, McNollgastians might lean in favor of limitations on outsider ex parte contacts with agency decisionmakers, inhibitions on off-record participation by staff members in the decisionmaking process, requirements of public oral hearings, and even cross-examination of agency experts. They would probably favor rigid enforcement of the existing APA provisions, for example by requiring resubmission of a proposed rule if the agency planned any significant changes. ${ }^{34}$ They might want to require the agency to respond in detail to every comment on pain of reversal. ${ }^{35}$ They would be attracted to schemes that require an agency to submit proposed rules to other agencies that would scrutinize them, furnish input, and have the legal or at least practical ability to sidetrack or veto the rule. ${ }^{36}$

Finally, McNollgastians might well take a strongly pro-judicial review stance. Such a stance would include pre-enforcement judicial review of rules ${ }^{37}$ with plenty of judicial hard looks at the factual underpinnings of rules as well as the rationality of the agency's judgment. ${ }^{38}$ Perhaps there should be high standards of justification that a rule must meet to survive review. ${ }^{39}$ Prompt and intense judicial review might facilitate oversight by drawing congressional attention to possible departures by the agency from the original coalitional deal; in addition, if sufficient hints of that deal can be planted in the statute, the judges could

33. Jonathan R. Macey, Organizational Design and Political Control of Administrative Agencies, 8 J.L. ECON. \& ORG. 93, 97-98 (1992); McNollgast, Structure and Procedure, supra note 1, at 441.

34. For an example of extremely strict enforcement of the APA rulemaking notice provision, see Shell Oil Co. v. EPA, 950 F.2d 741, 750-52 (D.C. Cir. 1991).

35. McGarity, supra note 25 , at $1400-01$, discusses the burdensome nature of the requirement that the agency answer all material comments; any slipup in responding to a comment could trigger judicial reversal with devastating consequences for the rulemaking project.

36. The prototype is submission of proposed rules to OMB under Executive Order 12,291. See supra note 28 . The enormous regulatory costs and delays attributable to the OMB referral requirement are well documented by E. Donald Elliott, TQM-ing OMB: Or Why Regulatory Review Under Executive Order 12291 Works Poorly And What President Clinton Should Do About It, 57 LAW \& CONTEMP. PROBS. 167 (Spring 1994); McGarity supra note 25, at 1428-36, 1448-50.

37. See Mashaw, supra note 23, at 221-29 (questioning the assumption that rules should normally be reviewable before they are actually applied to the plaintiff).

38. There is a vast literature on the hard look doctrine. For illumination of what we mean by "hard look," see Ronald M. Levin, Scope-Of-Review Doctrine Restated: An Administrative Law Section Report, 38 ADMIN. L. REV. 239, 246-60 (1986).

39. The most common example of this phenomenon is substitution of the substantial evidence test for the normal arbitrary and capricious test. Although it is unclear what Congress means by this substitution, some courts take the substantial evidence test to require them to engage in an intrusive form of judicial review of agency rules. See, e.g., Corrosion Proof Fittings v. EPA, 947 F.2d 1201, 122030 (5th Cir. 1991) (overturning EPA's asbestos regulations by second guessing the EPA's judgment that the health effects of banning asbestos justified the costs of doing so). 
actually enforce the contract when the rule is reviewed. ${ }^{40}$ Moreover, judicial reversal is itself a potent penalty that an agency might suffer if it strays from its proper role.

All these procedures, structures, and institutions might well be favored by people who want to enhance the abilities of the rulemaking process to steer agencies in a desired direction or to serve a fire alarm function. In general, I am opposed to doing these things. Each device would drive up the regulatory costs of rulemaking and foster what Mashaw calls "adversary legalism." ${ }^{41}$ Instead of launching a new wave of proceduralization, I would opt for the original APA skeleton model and for soft-look judicial review.

Regulatory costs can be extraordinarily high even under a bare-bones noticeand-comment regime and have now become nearly prohibitive under the various additional constraints, requirements, and hard looks already imposed by the executive, judicial, and legislative branches. ${ }^{42}$ The result is what Thomas McGarity and others have described as the "ossification" of the rulemaking process - the near abandonment of rulemaking and the substitution of various suboptimal regulatory techniques to achieve the same goals without incurring the costs. $^{43}$ This failure of rulemaking explains a great deal about why so many federal laws designed to protect consumers, workers, or the environment have been so ineffective. ${ }^{44}$

I fear that the McNollgast thesis can lead us to accept a set of rulemaking procedures and judicial review conventions that would be much more costly than the existing ones. Of course, McNollgast is not necessarily insensitive to the problem of regulatory cost; indeed Lupia and McCubbins rightly call attention to the costs an agency bears in making a proposal and bringing it to fruition. ${ }^{45}$ Nevertheless, there is little in the work of McNollgast or Lupia and McCubbins that points to the inevitable conflict between keeping regulatory costs down and building fire alarm systems.

40. See Motor Vehicle Mfg. Ass'n v. State Farm Mutual Automobile Ins. Co., 463 U.S. 29, 55 (1983) (stating that Congress wanted safety rather than cost to be paramount purpose of regulation). This is not self-evident, however, since a McNollgastian might fear that a court would nudge the agency in the direction that judges rather than the enacting Congress would prefer.

41. Mashaw, supra note 23 , at 250.

42. At the Law and Contemporary Problems conference, E. Donald Elliott (formerly general counsel of the Environmental Protection Agency) stated that it now costs the EPA about \$2 million and two years to adopt a rule-if it is pushing to get the rule out promptly and without considering the additional delays imposed by judicial review and potential judicial remand. This is horrendous. See E. Donald Elliott, 57 LAW \& CONTEMP. PROBS 167 (Spring 1994).

43. See generally Mashaw, supra note 23, at 195; McGarity, supra note 25. McGarity also observes that these same cost hurdles inhibit agencies from revising old, outdated, and inefficient rules or from adopting flexible, experimental rules.

44. See generally Mashaw, supra note 23; McGarity, supra note 25, at 1391.

45. See generally Lupia \& McCubbins, supra note 2. At the Law and Contemporary Problems symposium, Roger Noll strongly affirmed his concern with high costs and denied that McNollgast was ever indifferent to the problem of regulatory costs. And McNollgast originally pointed to the extremely negative effect on agency programs and delivery of services of imposing sanctions such as time consuming and highly publicized congressional investigations and midnight massacres. McNollgast, Administrative Procedures, supra note 1, at 252. 
I would like to suggest a simple model of bureaucratic behavior to predict the effect of increasing regulatory costs. Every agency has, in the short run, a fixed budget. Indeed, given present conditions of austerity at state and federal levels, the longer-term prospects probably favor declining budgets for most regulatory agencies-certainly in real terms. The agency also has a set of regulatory responsibilities. It cannot possibly discharge all of them. For example, it cannot perform needed economic or technical studies of the regulatory problem; it cannot adequately monitor the regulated industry to carry out its law enforcement function; it cannot prosecute more than a few of the most egregious violations of its rules; it cannot possibly launch and complete more than a few of the possible rulemaking initiatives that might be available; it cannot issue all of the regulatory guidance about existing rules that it should.

Given this condition of scarcity, an agency must make hard choices about the deployment of its limited resources. There are always other readily available substitutes for any particular use of resources. Faced with an increase in the cost of producing a particular bureaucratic product, an agency might produce the same quantity of that product but cut back somewhere else. For example, it might continue to make rules but reduce investigation and prosecution of violators. Or it might produce less of that particular output, leaving the resources devoted to the activity constant. Or it might reduce the resources devoted to that type of output and put the money somewhere else (for example, it might substitute adjudication for rulemaking).

Available evidence suggests that agencies are quite responsive to increases in the marginal cost of producing a given output. ${ }^{46}$ Increases in the costs of rulemaking, or increases in the intensity of judicial review of rules, tend to result in the production of fewer rules. Agencies tend to substitute other forms of regulatory outputs for rulemaking; for example, they use adjudication or informal guidance documents in lieu of rules. This is undesirable because the public has much less opportunity to participate in the making of law through adjudication or informal guidance ${ }^{47}$ because they tend to frustrate accountability mechanisms including legislative oversight, and because these expedients are less effective as tools to carry out the regulatory scheme.

A recent study of the behavior of California agencies lends support to my hypothesis $^{48}$ and to the findings of others who have questioned elaborate rulemaking procedure. This study focused on the production by California

46. These studies are discussed in McGarity, supra note 25, at 1385-96, 1412-13. See also JERRY L. Mashaw \& David L. HaRfST, The Struggle For Auto SaFeTY (1990); James T. Hamilton \& Christopher H. Schroeder, Strategic Regulators and the Choice of Rulemaking Procedures: The Selection of Formal vs. Informal Rules in Regulating Hazardous Waste, 57 LAW \& CONTEMP. PROBS. 111 (Spring 1994) (strategic substitution of informal EPA guidance documents for legislative rules); Richard J. Pierce, Jr., Unruly Judicial Review of Rulemaking, NAT. RESOURCES \& ENVT. 23 (Summer 1990).

47. See Robert A. Anthony, Interpretive Rules, Policy Statements, Guidances, Manuals, and the Like-Should Federal Agencies Use Them to Bind the Public?, 41 DUKE L.J. 1311 (1992) (misusing of policy statements, adopted without public participation, to bind the public).

48. Michael Asimow, Califormia Underground Regulations, 44 ADMIN. L. REV. 43 (1992). 
agencies of guidance documents such as interpretations, rulings, guidelines, policy statements, manuals, bulletins, and the like. Every agency should and must produce a steady flow of guidance material. ${ }^{49}$ It is vital that the affected public and the agency staff know how the agency interprets its rules and how it will exercise its discretion. This enables private sector regulatees to plan activities in a way that will minimize their costs and keep them out of trouble, and enables the staff to enforce the law in a uniform and efficient manner.

Under the federal APA, guidance documents (known as interpretive rules and policy statements) are exempt from rulemaking procedure; they can be adopted without any procedures at all $^{50}$ and are unlikely to be judicially reviewed in advance of their actual application to a regulatee. ${ }^{51}$ In California, they can be adopted only with full-fledged rulemaking procedures. ${ }^{52}$ Moreover, like all other rules, they must survive scrutiny by California's Office of Administrative Law ("OAL"). OAL is empowered to disapprove rules on the basis of lack of clarity, illegality, or a failure to demonstrate that the rule is not reasonably necessary in light of the facts in the rulemaking record. ${ }^{53}$ Thus California's system provides for verifiers, deck stacking, and fire alarms in abundance.

The combination of rulemaking procedure and the OAL approval requirement almost completely dried up the flow of guidance documents adopted in accordance with law. ${ }^{54}$ In lieu of producing such documents, agencies contrived other ways to guide regulated constituencies and agency staff. They used negotiated outcomes and informal adjudication instead of rulemaking; they sent individualized letters of advice but never generalized them; they advised staff through oral briefings but did not write down the guidelines; they stated that compliance with the guidelines was "voluntary"; they let it be known what sort of guidance the agency planned to issue in the future, but never got around to actually providing it; they went to the legislature for a change in the statute rather than adopting a rule.

49. See Michael Asimow, Advice to the Public from Federal Administrative Agencies (1973); Peter L. Strauss, Comment, The Rulemaking Continuum, 41 DUKE L.J. 1463, 1480-84 (1992).

50. APA \& 553(b)(A), (d)(2).

51. While guidance documents are sometimes subjected to pre-enforcement review, this is far more the exception than the rule. Generally, courts view such rules as unripe for review until they have actually been applied in practice. See Better Gov't Ass'n v. Department of State, 780 F.2d 86 (D.C. Cir. 1986) (holding that special circumstances render policy statement immediately reviewable); National Automatic Laundry \& Cleaning Council v. Shultz, 443 F.2d 689 (D.C. Cir. 1971) (holding that opinion letter signed by agency head ripe for review in light of serious practical consequences to industry of ignoring it).

52. California's rulemaking procedures are extremely demanding. They include all of the various innovations developed through federal case law (such as obligations to disclose material in the agency file and to respond to every comment) and go much further. For example, they require oral hearings on request and a whole array of impact statements and analyses. Asimow, supra note 48, at 48-50.

53. The California Code explicitly provides that no guidance document can be issued, utilized, or enforced unless adopted as a regulation and filed with the Secretary of State. CAL. GOV'T CODE \& 11347.5 (West 1992). This provision is strongly enforced by courts. See Asimow, supra note 48, at 53-55.

54. Asimow, supra note 48 , at 55-62. 
In some cases, agencies adopted guidance materials or manual supplements (or enforced existing ones) without following rulemaking procedures and hoped they would not get caught-a risky strategy in light of judicial sanctions for noncompliance. Finally, many agencies just did nothing at all to supply guidance and let everyone wonder what the correct interpretation was. In short, the study confirmed what the model would predict: since agencies can get by without issuing guidance documents, they are quite likely to substitute less costly alternatives for more costly ones. Confronted by high marginal costs of producing guidance, agencies turned to flouting the law, finding cheaper ways to furnish guidance, or providing no guidance at all.

III

CONCLUSION

Thus I return to the problem of regulatory cost. Broad and vague delegations of rulemaking power to agencies are an inevitable part of modern political life. Agencies should implement these mandates at minimal regulatory cost and as quickly as possible by adopting rules that are substantively accurate, achieve legislative goals at the least cost to regulatees, and are well publicized and strongly enforced. Increases in regulatory cost and in the intensity of judicial review have a powerful negative effect on the rulemaking function and the production of rules. Thus, we should be extremely cautious about increasing the costs of rulemaking.

My message is a familiar one: the best is the enemy of the good. More procedures-for such salutary purposes as enhancing legislative oversight -can and will produce quite negative impacts on the regulatory process. Pressed to the limits, the McNollgast hypothesis may lead its true believers to be indifferent to the problem of regulatory costs. That would be most unfortunate. The short title of this symposium is "Regulating Regulation." Sometimes "deregulating" regulation may be in the interests of all who want regulation to work. 
